v.9, n.3

Vitória-ES, jul.-sep. 2012

p. 71 - $93 \quad$ ISSN 1808-2386 DOI:http://dx.doi.org/10.15728/bbr.2012.9.3.4

\title{
Composition of the board and firm value of brazilian public companies
}

\author{
Enalto de Oliveira Gondrige ${ }^{\dagger}$ \\ Finance Secretariat at State of Santa Catarina \\ Ademir Clemente ${ }^{\Omega}$ \\ Federal University of Paraná - UFPR \\ Márcia Maria dos Santos Bortolocci Espejo ${ }^{¥}$ \\ Federal University of Paraná - UFPR
}

\begin{abstract}
The purpose of this paper is to investigate the relationship between the composition of boards of directors of Brazilian public companies and the firm value. The analysis is conducted by reference to a group of 208 Brazilian companies listed on Bovespa in the year 2008. The contribution of the study is done to assess the level of adherence to the recommendations of the Brazilian Institute of Corporate Governance (IBGC) regarding the composition of the board and its relation to market value. Using a multiple regression, three variables were studied: the level of board independence (Indep), accumulation of function by the Chief Executive Officer (CeoPowerful) and board size (Nmembros). The variable Nmembros was statistically significant, indicating positive correlation between corporate value and board size.
\end{abstract}

Keywords: Corporate governance; board of directors; Tobin's Q.

* Corresponding authors :

†. Master in Accounting at Federal University of Paraná - UFPR Affiliation: Finance Secretariat at State of Santa Catarina Address: Rod. SC 401, Km 05, 4600, Florianópolis - SC - Brazil

E-mail: enaltogondrige@hotmail.com Telephone: (47) 3643-6926

\footnotetext{
$\Omega$ Post-doctorate at University of London

Affiliation: Professor at Federal University of Paraná - UFPR Address: Av. Pref. Lothário Meissner, 632 - 1ㅇAㅁar, Jardim Botânico Curitiba - PR - Brazil

E-mail: ademir@ufpr.br

Telephone: (41) 3360-4413
}

\author{
¥ Doctorate in Controllership and \\ Accounting at University of São Paulo \\ Affiliation: Professor at Federal \\ University of Paraná - UFPR \\ Address: Av. Pref. Lothário Meissner, \\ 632 - 10 Andar, Jardim Botânico - \\ Curitiba - PR - Brazil \\ E-mail: : marciabortolocci@ufpr.br \\ Telephone: (41) 3360-4193
}

Editor's Note: This article was accepted by Bruno Funchal 


\section{INTRODUCTION}

he recent losses recognized by some Brazilian companies - Sadia, Aracruz, Votorantim - in operations with derivative financial instruments put the controllers of companies in crisis and investors on a collision course. These facts resume the discussion of agency conflicts - widely discussed by Jensen and Meckling (1976) - and of corporate governance mechanisms.

These mechanisms result from the change in the relations of ownership and control. The board is a major mechanism of governance, whose main objective is to minimize agency problems which can arise through monitoring of executives (FAMA, JENSEN, 1983a, 1983b).This monitoring carried out by members of the board of directors is necessary to protect the interests of all shareholders (JENSEN, 1993).

The board occupies a prominent position in the governance of corporations, performs the critical function of monitoring and advisory of managers. Andrade et al (2009, p. 6) point out that "the board of directors is seen as an agency which has the responsibility to decide on behalf of the owners. ".Common sense suggests that a higher level of board independence allows for a more effective monitoring and consequently, improves the performance of organizations (COLES, DANIEL; NAVENN, 2008).

Although this importance and theme are widely studied, to the extent the boards act in the interests of shareholders and are effective in controlling agency conflicts between managers and shareholders, a question remains: what is the relationship between board structure and corporate performance? The essence of the discussion about corporate governance is based on the possible influence that the structure of corporate governance internal and external mechanisms - may have on the results of organizations.

Several studies have documented that more independent boards (mostly outsiders) result in decisions more aligned to the interests or prospective of shareholders in performing various tasks such as hiring and dismissal of the CEO (WEISBACH, 1988), adoption of antitakeover measures (BRICKLEY COLES and TERRY, 1994), and compensation policies (BYRD, HICKMAN, 1992; COTTER; SHIVDASANI; ZENNER, 1997 apud COLES, DANIEL; NAVENN, 2008).

Evidences from these studies on the effectiveness of the boards are quite varied. Some studies indicate that the boards of directors whose proportion of independent members is greater make decisions more aligned with shareholders' interests (HELLAND; SYKUTA, 2003; PANASIAN; PREVOST; BHABRA, 2004; ANDRADE et al, 2009). Other studies 
have found no relationship or found a negative relationship between performance, market value (Tobin's Q) and the composition of the board (YERMACK, 1996; EISENBERG; SUNDGREN; WELLS, 1998; BHAGAT; BLACK, 1999).

The stock market crisis , in 2008 , created a source of tension - the relationship between boards of directors, investors, and controllers - in companies that suffer most from the decline in shares and, consequently, with the decline in its market value. In private firms the board is only a dramatic play in which the protagonists only ratify the decisions of the controllers. In public companies, the board has a duty to defend the interests of the business (JENSEN, 1986), or may personally respond for damages to shareholders. In that sense, the independence of the advice is recommended and requires good governance practice (AGRAWAL; KNOEBER, 1996).

Among the recommendations of IBGC through the code of best corporate governance practices (CMPGC) the structure of the board is highlighted. Regardless of its form of incorporation, every organization must have a board of directors elected by the shareholders, whose main mission is to "protect and enhance the assets and maximize return on investment" (CMPGC, 2004, GAC p.18).

Among the powers of the board, the definition of strategy, election and dismissal of the chief executive officer (CEO), the approval of choice or dismissal of other executives as proposed by the CEO, monitoring management and risks are noteworthy. These activities directly affect the generation of cash flows that consequently influence the value of the shares of companies. Thus, the research question that guides this study is: Is there any relationship between the structure of the board and the value of publicly traded Brazilian companies listed on Bovespa?

This study aims at investigating if there is any relation between the structure of the board and the value of publicly traded Brazilian companies listed on Bovespa. As secondary objectives this study means to analyze the evolution of corporate governance practices, regarding the independence of the dimension of councils and the accumulation of office of president by the chief executive on the board.

\section{THEORETICAL REFERENCE}

The literature review will include reflections on the separation of ownership and control, aspects of corporate governance, as well as its mechanisms, and the board. 


\subsection{Separation of ownership and control}

Jensen and Meckling (1976, p.308) define an agency relationship as "a contract in which one or more persons (the principals) hire another person (the agent) to perform some service on their behalf, which involves delegating some authority for the decision making of the agent". The relationship between shareholders and managers of a company with diffuse ownership is a classic example of an agency relationship.

According to Ross (1973), the agency relationship is the oldest and most common form of social interaction. Essentially all forms of contracts, such as the ones between employer and employee, between government and governed, contain important elements of agency. An agency relationship exists between two or more parties when one, named as agent, on behalf or as representative of another, known as the principal decides on behalf of the principal.

Indeed, one is able to observe that the principal-agent relationship does not appear only in the firm. It may appear, for example, when a political representative is elected or when someone sends an attorney. However, such relationship is not present in all contracts of the firm, for example, contracts with suppliers and customers, but only those contracts whose related parties are the owners and executive managers (IUDÍCIBUS and LOPES, 2004).

Thus, the agency relationship involves some degree of delegation of power from the principal to the agent for a decision on his behalf. Such relationship may indicate the pursuit of professionalism, since the owner delegates to the executive manager the commission of managing and of maximizing his resources. Jensen and Meckling (1976) argue that, if the parties act with the purpose of maximizing their personal utilities, there is good reason to believe that the agent does not always act on behalf of the interests of the principal. Such differences of interest can be mitigated through creation of appropriate compensation policies for the agent and also providing some form of monitoring of the activities of the manager.

However, when the manager is the sole owner of the capital of an enterprise, there is no separation of ownership and control and, therefore, no agency problem between the manager and owner, since the two functions are unified. In contrast, when the property is diffused among many foreign investors, as in the case of most publicly traded corporations, the separation of ownership and control leads to the potential divergence of interests between owners and managers.

\subsection{Corporate Governance}




\subsubsection{Concept and Definition of Corporate Governance}

Corporate governance, according to Shleifer and Vishny (1997), is the mechanism by which the investor ensures the return on invested capital. And yet, a set of constraints administrators apply to themselves or that investors apply on executives, in order to reduce the misapplication of/0\} ex post resources and to encourage investors to invest more ex ante resources.

According to La porta et al (2000, p.4), "corporate governance is the set of mechanisms through which investors (outsiders) protect themselves against the expropriation of executives (insiders). "In Brazil, Carvalhal-da-Silva and Leal (2007, GAC, p. 23) define corporate governance as "[...] mechanisms or principles that govern the decision making process within a company. Corporate governance is a set of rules that aim at minimizing agency problems. "Such problems occur when the interests between the executive and shareholders conflict. Although the executive must always act with the goal of maximizing shareholder wealth, there are situations where this does not occur, giving rise to the emergence of opportunistic behavior of the executive.

\subsubsection{Scope of Corporate Governance}

According to Hart (1995, GAC p. 678), corporate governance is useful in a business if two conditions are present. First, there must be an agency problem or conflict of interests between members of the organization, maybe owners, managers, workers or consumers. Second, because transaction costs are such that the agency problem cannot be resolved by contract, i.e., there is the so-called incomplete contract.

The author argues that, in the absence of agency conflict, all individuals associated with the organization can be instructed in order to maximize the wealth of the owners or the value of the company or minimizing costs. Individuals would be prepared to perform their activities regardless of how organizations conducted their activities. In that situation, financial incentives would not be necessary to motivate people. Nor would a governance structure be necessary to resolve differences which would not exist.

\subsubsection{Mechanisms of Corporate Governance}

According to Jensen (1993), there are four control forces acting on the company to resolve the problems caused by conflict between the decisions of managers and those 
appropriate in view of society, namely: capital markets, legal and regulatory system, competitive market forces, and internal control mechanisms.

By analyzing specific mechanism of corporate governance, there actually are two main issues. First, will the mechanism in question serve to align the interests of managers and shareholders - and, if so, how? Second, does the mechanism in question t have a significant impact on the performance or value of the company?

Shleifer and Vishny (1997, pages 14-15) indicate that most of the evidence that managers do not always act in the interests of their shareholders comes from the many studies of events which have been conducted. In these studies, researchers evaluate whether there is an abnormal reaction in the stock price at the announcement of a particular type of event. If the reaction is, on average, significantly negative, then, this suggests that the measure is not, in general, interest of shareholders.

This allows addressing the first question about whether a particular corporate governance mechanism reduces the distance between the interests of managers and shareholders. According to Denis (2001, p. 197) "whether a particular mechanism reduces the probability of a manager carrying out any measure that reduces the value of the shareholder share, so, this mechanism seems to align the interests of managers and shareholders, at least in some extent. " In view of the author, the same can be said if the stock price reaction to a particular event is positively related to the presence of a particular governance mechanism.

Considering that the interests of shareholders, with respect to their investments , whether purely financial (HE and SOMMER, 2006), theoretically, if a mechanism aligns the interests between managers and shareholders, automatically they should also result in the maximization of shareholder investments (DENIS, 2001). However, it can be difficult to find empirical evidence consistent with this statement, even if this is true. Furthermore, evidence suggests that the relationship between mechanisms of corporate governance and firm value should be interpreted with caution as they may be spurious. The great challenge of these studies is the endogeneity (BORSCH-SUPAN and KOKE, 2000; HERMALIN and WEISBACH, 2003), which is presented as a curse or as a challenge, in empirical studies on corporate governance.

\subsubsection{The Board of Directors}

First of all, we must reflect on one question: why are there boards of directors? According to Hermalin and Weisbach (2003), one possible answer is that they are, simply, a product of legal and regulatory system, resulting from imposition of a state or imposition of 
stock exchanges by governance codes or different levels of governance. Most companies are required to have a board that brings together a large number of requirements: must have, in Brazil, at least three members; shall meet with some regularity; it may be necessary to have several committees; and a fraction of the directors must have some level of management independence.

However, the statement cannot be an absolute truth. Boards of directors are prevalent throughout the world in a variety of commercial and non-profit organizations; more importantly, the existence of these boards precedes these regulations (HERMALIN and WEISBACH, 2003). In addition, Hermalin and Weisbach (2003, p. 9) state that "If the councils exist simply to satisfy regulatory requirements, they would represent costs to companies, which subsequently, through lobbying, the regulations would be eliminated, at least in some places in the world."

However, the available evidence suggest otherwise. Legislation sets a minimum number of members. However, in practice, the boards are generally much larger than required by law. In this study, it was found that in 570 publicly traded companies, more than ninety percent of them have more than three members. Thus, if the existence of councils were simply the result of legal fictions, organizations would apply the minimum required by law.

Given its prevalence over time in different organizational forms, there must be an explanation for the existence of boards other than merely the result of regulation. According to Hermalin and Weisbach (2003), the most plausible hypothesis is that boards are a solution to some organizational problems, determined endogenously in organizations and that would solve common agency problems in large companies.

According to CMPGC (2004), regardless of its corporate form and being a publicly traded or private company, every organization must have a board of directors elected by the members, whose primary mission is to protect and enhance the assets and maximize return on investment. The independence of the board regarding the management of companies is one of the indispensable attributes and is related to the presence of outside directors. According Carvalhal-da-Silva and Leal (2005), an independent board requires good governance practice, since this board is responsible for evaluating the directors and replacing them, if it is the interest of shareholders. In the same sense, Hart (1995, GAC p. 5) states that management control is assured by the board.

From the powers of the Board, the "[...] definition of strategy, the election and dismissal of the CEO, approval or waiver of the choice or dismissal of other executives, on 
proposal of the $\mathrm{CEO}$, monitoring of management, risk monitoring and appointment and replacement of the independent auditors are noteworthy "(CMPGC, 2004, p. 11).

According to Carvalhal-da-Silva and Leal (2005), the board size is an important control mechanism, since one of the tasks is to monitor the management of the company. Likewise, Jensen (1993, p. 34), argues that the board is the main factor of success of a system of internal control, and more than that, it sets the rules for the CEO and has final responsibility for the operation of the organization. In the evaluation of Jensen (1993) and Lipton and Lorsch (1992), boards with more than seven or eight members are less efficient than smaller boards.

\section{METHODOLOGY}

In this section, the method and research procedures are presented, in order to answer to the following research question: Is there any relationship between the structure of the board and the value of publicly traded Brazilian companies listed on Bovespa?

\subsection{Definition of the Population and Sample}

In this study, annual information concerning the Balance Sheets and Statements of Income, obtained from Economatica ${ }^{\circledR}$ database were considered. In addition, we considered the Reports of Annual Information (IAN) and the Quarterly Information Reports, which the companies issue to the Securities and Exchange Commission (CVM). Thus, we studied 19 companies in economic sectors, which are listed in Table 1.

TABLE 1 - FREQUENCY OF COMPANIES PARTICIPATING IN THE RESEARCH PER SECTOR OF THE ECONOMY

\begin{tabular}{|c|c|c|c|c|c|}
\hline Sector & Frequency & $\%$ & Sector & Frequency & $\%$ \\
\hline Agricultural and Fisheries & 4 & 1.9 & Pulp and Paper & 4 & 1.9 \\
\hline Food and Beverages & 16 & $7.7 \%$ & Oil and Gas & 3 & 1.4 \\
\hline Trade & 10 & 4.8 & Chemistry & 10 & 4.8 \\
\hline Construction & 23 & 11.1 & Steel \& Metallurgy & 16 & $7.7 \%$ \\
\hline Electronics & 5 & 2.4 & Software and Data & 1 & $0.5 \%$ \\
\hline Electricity & 21 & 10.1 & Telecommunications & 11 & 5.3 \\
\hline Industrial Machinery & 4 & 1.9 & Textiles & 15 & 7.2 \\
\hline
\end{tabular}




\begin{tabular}{|c|c|c|c|c|c|}
\hline Mining & 2 & 1.0 & Transportation Services & 9 & 4.3 \\
\hline Nonmetallic Mineral & 3 & 1.4 & Vehicles and parts & 10 & 4.8 \\
\hline \multirow[t]{2}{*}{ Other } & 41 & 19.7 & & & \\
\hline & & & Total & 208 & 100 \\
\hline
\end{tabular}

Note: The classification of companies in sectors took place according to criteria of Economática®.

TABLE 2 - FREQUENCY OF THE COMPANIES PARTICIPATING IN THE RESEARCH PER SEGMENT

\begin{tabular}{|c|c|c|c|c|c|}
\hline Sector & Frequency & $\%$ & Sector & Frequency & $\%$ \\
\hline Traditional Bovespa & 82 & 39.4 & Level 1 & 29 & 13.9 \\
\hline BDR & 2 & 1.0 & Level 2 & 9 & 4.3 \\
\hline \multirow[t]{2}{*}{ Traditional OTC } & 1 & $0.5 \%$ & New Market & 85 & 40.9 \\
\hline & & & Total & 208 & 100 \\
\hline
\end{tabular}

Note: The classification of companies in sectors took place according to criteria of Economática®.

In September 2008, there were 536 companies listed on the São Paulo Stock Exchange, among which, only considering the manufacturing firms with data available until the third quarter of the year studied, 227 had data in the Economatica® database. After the collection and data analysis, we proceeded to the exclusion of companies which presented data are inconsistent or incomplete, resulting in a total of 208 companies.

\subsection{Theoretical and operational definition of variables}

This study aims to investigate if the composition of the board relates to the market value of open capital Brazilian companies. The composition of the board acts as an independent variable, while the company's value acts as a dependent variable. The choice of variables - dependent, independent and control - has, as its foundation, studies of Panasian, Bhabra and Prevost and Bhabra (2004), Bhagat and Black (1999), Fuerst and Kang (2000), Yermack (1996), Coleman and Biekpe ( 2005), Cheng (2008), Silveira Barros and Fama (2003), Silveira (2004) and Carvalhal-da-Silva (2002).

\subsubsection{Theoretical and operational definition of independent variables}

The Brazilian Corporate Law provides that the Board of Directors is composed of at least three members. While the code of best corporate governance practices recommends that 
the structure of such board should have between five and nine members, depending on the profile of the company. It is also recommend that there should be no concentration of power at the expense of proper management supervision, and the accumulation of functions of the chairperson and chief executive officer (CEO) should be avoided. Thus, the structure of the board in this study is defined by the use of three independent variables:

$\checkmark$ CEO occupying the position of chairman of the board - binary variable, in which:

CeoPowerful $=1$ if the CEO also occupies the position of chairman of the board.

CeoPowerful $=0$, if the position of chairman is not occupied by the chief executive.

$\checkmark$ Level of independence of the board: proxy (ratio of external members minus the ratio of internal members). This variable is set with basis on the study by Bhagat and Black (2001), Silveira, Barros and Fama (2003). Despite other studies only considering the total of external members, this methodology is used, , for being put into a comparative framework to the proportion of internal members.

$$
\text { Indep }=\left(\frac{\text { EXT }}{\text { TOTAL }}\right)-\left(\frac{\mathrm{INT}}{\text { TOTAL }}\right)
$$

Indep - Level of independence of the board;

Total - Total of members of the board;

Ext - the number of members who do not exercise executive function;

Int - number of members who exercise executive function.

Size of the board - NMembros, variable represented by the ratio between the total number of members and assets of the company. This metric is used as an attempt to relativize the size of the board and the size of the companies.

\subsubsection{Theoretical and operational definition of the dependent variable}

This study focuses on the possible relationship between the structure of the board and the market value of Brazilian companies. In order to verify such consistency, we use the Tobin's Q indicator. Such indicator has been used in several governance studies, for example, Agrawal and Knoeber (1996), Yermack (1996) and Bhagat and Black (1999) Cheng (2008), Panasian, Prevost and Bhabra (2004), Faleye (2007) Silveira, Barros and Fama (2003), Silveira (2004) and Carvalhal-da-Silva (2002). According to Fama and Barros (2000), the Q is defined as the ratio between the market value of a company and the replacement value of its 
assets and expresses the value of the company in a sense of performance, making it an indicator readily comparable from company to company. In this study, the square root of Tobin's Q is used as a proxy for the value of the corporation. Such transformation is necessary to correct the non-normality and the heteroscedasticity (Hair et al, 2005).

$$
\mathrm{Q}=\frac{\text { Valor de Mercado das Ações }+ \text { Valor de Mercado das dívidas }}{\text { Valor de Reposição dos ativos }}
$$

Except for the value of shares, the remaining data are not directly observable. In the absence or inability to obtain such data, approximations of Tobin's Q are used. Fama and Barros (2000) suggest as alternative to "theoretically correct" methods, but of difficult practical application, the use of simplified methods as Chung and Pruitt (1994), Shin and Stulz (2000). In this study, we chose to use the Tobin's Q estimated by the Chung and Pruitt (1994, p. 72), model who define it as:

$$
\mathrm{Q} \text { de Tobin } \cong \frac{\left(\mathrm{VMAO}^{*} \mathrm{Qtd}\right)+(\mathrm{VMAP} * \mathrm{Qtd})+\mathrm{DIV}}{\mathrm{AT}}
$$

In which:

VMAO - Market value of common shares;

VMAP - market value of preferred shares;

DIV - book value of debt and long-term minus current assets, excluding the value of stocks;

AT - Total assets of the company;

QTY - Quantity of shares issued.

\subsubsection{Control variables}

These variables are included in the model for exercising some level of influence on the dependent and independent variables. The following control variables were used:

$\checkmark$ Capital Structure: defined as the degree of leverage (Alav), i.e., the total financial debt over total assets of the company at the end of each financial year. 
$\checkmark$ Level of corporate governance (Ngov): this dummy variable computes 1 for each company that is listed in one of the best levels of corporate governance practices of BOVESPA and 0 for companies that are not.

\subsubsection{Model Specification}

With the objective of investigating the possible relationship between the structure of the board and the value of publicly traded companies with shares traded on the stock exchange in Sao Paulo and assess whether these companies follow the recommendations of IBGC, research estimated the following econometric model:

$$
\begin{aligned}
& Q_{i}=\beta_{0}+\beta_{1} \text { Indep }_{i}+\beta_{2} \text { NMembros }_{i}+\beta_{3} \text { CeoPowerful }_{i}+ \\
& \beta_{4} \text { Alav }_{i}+\beta_{5} \text { Ngov }+\varepsilon_{i}
\end{aligned}
$$

In which:

$\mathrm{Q}_{\mathrm{i}}$ - proxy for the market value of companies, ratio between the market value of debt and the replacement value of assets;

$\beta_{0}=$ Is the intercept of the regression model;

Indep $_{\mathrm{i}}$ - level of independence of the board;

NMembros $\mathrm{i}$ - total number of board members relativized in relation to company size;

CeoPowerful $\mathrm{i}_{\mathrm{i}}$ - binary variable that identifies the presence or absence of accumulation of positions by the chief executive;

Alav $_{\mathrm{i}}$ - ratio between total debt and total assets;

$\mathrm{Ngov}_{\mathrm{i}}$ - level of corporate governance, Dummy for companies with different levels.

$\varepsilon_{i}$ - random error term of the model.

\subsection{Data Collection}

Data collection occurred secondarily through the websites of the São Paulo Stock Exchange by the system of External Disclosure ITR / DFP / IAN, the Securities and Exchange Commission, and the Economática ${ }^{\circledR}$ software. We collected information on the composition of the boards of directors of the Bovespa database in the third quarter of 2008, latest 
information of each company, considering only the active members. The financial information that makes up Tobin's Q proxy are accumulated values between the months of January through September of 2008.

\subsection{Treatment of Data}

For the execution of this study we used:

a) Jarque-Bera Normality Test: confirms if a data set follows normal distribution;

b) Breusch-Pagan Homoskedasticity Test: checks if the error terms of the linear regression model have the same variance;

c) F and $t$ test;

d) Multiple linear regression analysis.

We adopt, for the interpretation of results, significance level $\alpha$, of 5\%, i.e., $\alpha=$ 0.05.Thus, when the p-value of a hypothesis test is less than the chosen value of $\alpha$, the test procedure leads to rejection of null hypothesis (HILL, GRIGGITHS, JUDGE, 2006, p.119).

\section{Results Analysis}

\subsection{Descriptive Statistics of board compositions}

The information concerning the structure variables of the board are summarized in the following tables.

TABLE 3 - COMPOSITION OF THE BOARD OF DIRECTORS IN 2008

\begin{tabular}{|c|c|c|c|c|}
\hline & Minimum & Maximum & Average & Standard Deviation \\
\hline Independence & 0.40 & 1.00 & 0.8574 & 0.13893 \\
\hline Independence (int ratio- ext ratio) & -0.20 & 1.00 & 0.7149 & 0.27786 \\
\hline Total Members & 2 & 17 & 7.0817 & 2.75366 \\
\hline Tobim's $Q_{\text {adjust }}$ & .34 & 2.00 & 1.0168 & 0.33157 \\
\hline External & 2 & 16 & 6.1971 & 2.86316 \\
\hline Internal & 0 & 4 & .8846 & 0.90418 \\
\hline
\end{tabular}


Table 3, which summarizes the information of all member companies of the sample, one is able to observe that, on average, $85.74 \%$ of directors do not perform executive activities in the organization and that, on average, when considering the independence as the difference in ratio between external members and internal members, the percentage of independence decreases to $71.49 \%$. The total membership of the board, on average, $7.08 \%$, is within the range between five and nine members recommended by the code of best corporate governance practices of IBGC, as well as the size suggested by Lipton and Lorsch (1992) and Jensen (1993).

These results are similar to those found by He and Sommer (2006), who found, in that study, that boards, on average, have 9 members, and the percentage of outsiders (nonfamily and non-executive) is, on average, 78\%.Andrade et al (2009), analyzed 147 companies, in the period from 2004 to 2006, and showed similar results about the independence of boards. It was verified that, in our sample, on average, $88 \%$ of the size of the board is formed by independent persons. Studies Yermack (1996), Eisenberg, Sundgren and Wells (1998) studies, indicate a negative association between board size and corporate performance. According to Cheng (2008), this relationship is consistent with the view that coordination and communication tend to decrease as the board increases.

Lipton and Lorsch (1992) argue that, normally, directors do not criticize the policies of the managers or do not impartially evaluate corporate performance. These problems are more evident on larger boards, because the efficiency in monitoring decreases the proportion of the size of the board. According to Lipton and Lorsch (1992, p. 14), when a board has more than ten members, it becomes harder for everyone to express their ideas and opinions in the short time available.

Similarly, Jensen (1993, p.44) concludes that "when a board has more than seven or eight members, they are less likely to work effectively and are easier to be controlled by the CEO."When a board is larger, it is more difficult for the company to organize meetings and even harder to reach a consensus. Consequently, larger boards are less efficient and slower in decision making. Moreover, Cheng (2008) found an inverse relationship between board size and variability of corporate performance. 
TABLE 4 - MATRIX OF PEARSON CORRELATION BETWEEN THE STUDIED VARIABLES

\begin{tabular}{|c|c|c|c|c|c|c|}
\hline & Tobin's Q & Indep & NMembros & CeoPowerful & Alav & NGov \\
\hline Tobin's Q & 1 & -026 & $.290 * *$ & -041 & $.275^{* *}$ & -.097 \\
\hline Sig. & & .705 & .000 & .553 & .000 & .162 \\
\hline Indep & -.026 & 1 & -.063 & $-.566 * *$ & -.079 & $224 * *$ \\
\hline Sig. & .705 & & .363 & .000 & .257 & .001 \\
\hline NMembros & $.290 * *$ & -.063 & 1 & .130 & $.493 * *$ & $-.279 * *$ \\
\hline Sig. & .000 & .363 & & .062 & .000 & .000 \\
\hline CeoPowerful & -.041 & $.566 * *$ & .130 & 1 & .055 & -.153 \\
\hline Sig. & .553 & .000 & .062 & & .426 & .027 \\
\hline Alav & $.275^{* *}$ & -.079 & $.493 * *$ & .055 & 1 & $-.315 * *$ \\
\hline Sig. & .000 & .257 & .000 & .426 & & .000 \\
\hline NGov & -.097 & $.224 * *$ & $.279 * *$ & $-.153 *$ & $-.315 * *$ & 1 \\
\hline Sig. & .162 & .001 & .000 & .027 & .000 & \\
\hline
\end{tabular}

** Significant correlation at 0.01 (bilateral)

* Significant correlation at 0.05 (bilateral)

The results show a positive correlation between the size of the board and Tobin's Q, indicating that the higher the board, the greater the value of companies. Among the ALAV and NMembros variables, there is a moderate positive correlation, indicating that more leveraged companies have larger boards. The Ceopowerful variable showed significant negative correlation to the level of independence, indicating that the larger the board, the lower the probability of accumulation of the chief executive position as chairman of the board, result quite similar to that found by Andrade et al (2009) .The NGov variable correlates positively with the Indep and NMembros variables, indicating that companies with different levels of governance have larger boards and higher proportion of members outside the organization.

Those results should be carefully analyzed, since there are methodological differences regarding the metrics of the variables under study. The most relevant results indicate no correlation between Tobin's Q and the level of independence and positive correlation between Tobin's Q and board size. As the size of the board increases, business performance increases.

Table 5, presents the recommendations of CMPGP (2004), regarding the composition of boards - size of the board from five to nine members, different persons holding the positions of CEO and chairman - and the level of adherence of Brazilian member companies of the sample. 
TABLE 5 - RECOMMENDATION OF IBGC

\begin{tabular}{|c|c|c|}
\hline Category & Frequency & $\%$ \\
\hline Councils with less than five members & 3 & 14.90 \\
\hline Councils between five and nine members & 143 & 68.8 \\
\hline Councils with more than nine members & 34 & 16.30 \\
\hline Total & 208 & 100 \\
\hline $\begin{array}{r}\text { Different people in the position of Chief Executive and } \\
\text { the Council Presidency }\end{array}$ & 145 & 69.70 \\
\hline
\end{tabular}

These results show that most companies follow the recommendations of CMPGC (2004), regarding the size of the board. It is found that $68.8 \%$ of companies follow such recommendation. In contrast, $14.9 \%$ of companies have boards with less than five members. With respect to the accumulation of CEO and chairman positions, the Brazilian legislation allows the functions to be performed by the same person. This study, evidences that, in $31.3 \%$ of the observations, the CEO and chairman are the same person. Ventura (2000) apud Leal and Oliveira (2002, GAC p. 23) found that this occurred in $41 \%$ of companies. One is able to observe a change in relation to the recommendation of different people performing this task.

\subsection{Multiple Linear Regression Analysis}

\subsubsection{Verification of assumptions}

The standard linear regression model assumes that each error term is normally distributed, i.e., in a more compact manner $\mu_{i} \sim N\left(0, \sigma^{2}\right)$, Gujarati (2006, p.88). With the objective of verifying this premise the Jarque-Bera normality test was taken. According to Sartoris (2003: GAC p. 253) this test is based on measures of skewness and kurtosis, under the null hypothesis that the residuals are normally distributed. The $J B$ statistics converges, asymptotically, to a $\chi^{2}$ distribution with two degrees of freedom. These results indicate that residues follow a normal distribution, thereby rejecting the event of a breach of the premise of the regression model.

\section{TABLE 6 - JARQUE-BERA TEST OF NORMALITY OF RESIDUALS}

\begin{tabular}{|c|c|c|}
\hline$X$-squared & (2) & p-value \\
\hline 0.3711 & 2 & 0.8306 \\
\hline
\end{tabular}


Multicollinearity is present when there is high correlation between two or more explanatory variables (SARTORIS, 2003; GUJARATI, 2006). It is noted, in Table 4, that there is high correlation between the explanatory variables. According to Sartoris (2003, p.294) and Gujarati (2006, p. 285), another way to identify multicollinearity is to obtain a highly significant $\mathrm{F}$ test followed by little significant t-statistics for the coefficients. According to Gujarati (2006, p. 280), "even if multicollinearity is very high, as is the case of near multicollinearity, the ordinary least square estimators still guard the property of best nontendentious linear estimators." Still, according to the author, imperfect multicollinearity does not violate any assumption of the Classical Linear Regression Model (MCRL), and would only be a serious problem if the correlation coefficients between the regressors were greater than 0.8.Considering that none of the variables exceeded 0.8 , this study assumes the absence of multicollinearity.

According to Gujarati (2006, p. 314), the heteroscedasticity may result from the presence of divergent data, the omission of important variables for the model and also the intrinsic characteristic phenomena of an economic nature. The Breusch-Pagan test checks the null hypothesis that the variance of non-observable effects is equal to zero. When the variance of the error terms is increasing or fluctuating, it is said that the data are heteroscedastic (Table 7).

TABLE 7: BREUSCH-PAGAN TEST OF HOMOSCEDASTICITY

\begin{tabular}{r|r|r}
\hline BP & df & p-value \\
\hline 10.9551 & 5 & 0.05228 \\
\hline
\end{tabular}

According to Gujarati (2006, p.332), the Breusch-Pagan test converges, asymptotically, for a distribution of $\chi^{2}$ chi-square (1-m) degrees of freedom. Thus, the critical value at $5 \%$ is 11.0705 . So, as the calculated value is smaller, the hypothesis of homoscedasticity is not rejected.

\subsubsection{Analysis of Regression Results}

As the scope of this study was to verify if the market value of publicly traded companies can be explained by the structure of the board, we performed multiple linear regression with 208 companies for the year 2008. According to Hair et al (2005, p.144)," the multiple regression analysis, a form of general linear modeling, is a multivariate statistical technique used to examine the relationship between a single dependent variable and a set of independent variables. "Still, according to the authors, the multiple regression method is 
appropriate when you want to objectively assess the degree and character of the relationship between dependent and independent variables.

TABLE 8 - REGRESSION RESULTS BETWEEN TOBIN'S Q AND BOARD STRUCTURE

\begin{tabular}{|c|c|c|c|c|}
\hline Variable & Coefficient & Standard Error & Statistic t & P-value \\
\hline Intersection & 1.0004865 & 0.0909786 & 10,997 & $<2 \mathrm{e} 16 * * *$ \\
\hline Indep & -0.0806525 & 0.0973686 & -0828 & 0.4085 \\
\hline NMembros & 0.0020238 & 0.0007147 & 2832 & $0.0051 * *$ \\
\hline CeoPowerful & -0.0829700 & 0.0582072 & -1425 & 0.1556 \\
\hline Alav & 0.1328700 & 0.0597238 & 2225 & $0.0272 *$ \\
\hline Ngov & 0.0107388 & 0.0487916 & 0220 & 0.8260 \\
\hline R-SQUARE & 0.1162 & & & \\
\hline ADJUSTED R-SQUARE & 0.0935 & & & \\
\hline
\end{tabular}

The coefficient of determination or explanation adjusted $\mathrm{R}^{2}$ is the descriptive measure of quality of model adjustment. In the case of multiple regression, the value of adjusted $\mathrm{R}^{2}$ represents the combined effect of any statistical variable in the prediction. In the present study, $\mathrm{R}^{2}$ is adjusted to 0.0935 , indicating that $9.35 \%$ of the variation of the dependent variable is explained by the independent variables.

The multiple linear regression model used five independent variables, and was estimated by ordinary least squares procedure. From the $t$ tests associated with the parameters shown in table 8 , it is evident that the significant variables in the model are the size of the board and leverage, with positive coefficients. This finding, despite being low correlation, differs from one part of the literature (Bhagat and Black, 1999, 2001; YERMACK, 1996; EISENBERG, SUNDGREN and WELLS, 1998; SILVEIRA, BARROS and FAMA, 2003), which states no relationship between board size and value of companies or have a negative relationship. However, this result, subject to the methodological differences in the construction of variables, is convergent with the results obtained by Andrade et al (2009), wherein one of the findings is that the total amount of directors was positively related to the value of companies market. 


\subsubsection{Analysis of Variance}

The $\mathrm{F}$ test is intended to test the joint effect of the explanatory variables on the dependent variable. This means verifying if at least one of the explanatory variables of the model effectively has, influence on the dependent variable. For a level of significance $\alpha=$ 0.05 , the value of the calculated F statistic is 5.313, greater than the tabulated value of 4.39 . In that case, as the calculated value is greater than the tabulated value, $\mathrm{H}_{0}$ is rejected, concluding, with a $5 \%$ risk, that there is multiple linear regression, i.e., the structure of the board can predict and explain the proxy (Tobin's Q) of market value of Brazilian companies (Table 9).

TABLE 9 - ANOVA

\begin{tabular}{l|r|r|r|r|r}
\hline \multicolumn{1}{l|}{ ANOVA } & \multicolumn{1}{|c|}{ Gl } & \multicolumn{1}{c}{ SQ } & MQ . & F Test & Significance of F \\
\hline Regression & 5 & 2645 & 0529 & 5313 & 0.0001308 \\
\hline Residue & 202 & 20,112 & 0100 & & \\
\hline Total & 207 & 22,757 & & & \\
\hline
\end{tabular}

\section{CONCLUSIONS}

The main objective of this study was to investigate whether a relationship exists between the structure of the board and the value of publicly traded Brazilian companies listed on Bovespa. The variables that showed statistical significance were the size of the board and leverage, positively related to firm value. The study identified that the most valued companies tend to have higher number of directors and, on average, a higher percentage of independent directors.

A variable of degree of independence was not statistically significant, results convergent with the one found by Andrade et al (2009). The variable CeoPowerful did not present statistical significant, convergent result with the one found by Andrade et al (2009), contradicting the results of Silveira, Barros and Fama (2003), as these authors presented results that indicate a greater appreciation of the companies which positions of chairman and CEO are held by different people.

The presented results, although they find evidence, definitely do not provide conclusive evidence, considering the insignificance of some coefficients between the variables of governance and market value. Possible causes of this insignificance may be due to methodological limitations, once the study was developed for a relatively short timeline. 
However this research points out that the boards are part of the solution to agency problems of most organizations. Visualizing the boards from this perspective is the most useful way to study how they are structured and their function.

As a suggestion for future studies, it is recommended to increase the period of analysis with a panel data approach, in order to capture the evolution of levels of adherence to the recommendations of IBGC. Also other variables may be included, for example, Brazilian companies that have ADRs abroad, which allow verifying if the structure of the board of those have significant influence.

\section{REFERENCES}

AGRAWAL, Anup; KNOEBER, Charles R. Firm performance and mechanisms to control agency problems between managers and shareholders. The Journal of Financial and Quantitative Analysis, v. 31, n. 3, p. 377-397, set. 1996.

ANDERSON, Rolph E. et. al. Análise multivariada de dados. 5. ed. Porto Alegre: Bookman, 2005.

ANDRADE, Lélis Pedro de et al. Governança corporativa: uma análise da relação do conselho de administração com o valor de mercado e desempenho das empresas brasileiras.

Revista de Administração Mackenzie, v. 10, n. 4, p. 4-31, 2009.

BHAGAT, Sanjai, BLACK, Bernard. The uncertain relationship between board composition and firm performance. Business Lawyer, v. 54, p. 921-63, 1999.

BÖRSCH-SUPAN, Axel; KÖKE, Jens. An applied econometricians' view of empirical corporate governance studies. ZEW discussion papers, n. 00-17, 2000. Disponível em: <http://papers.ssrn.com/sol3/papers.cfm?abstract_id=373383〉. Acesso em: 15 jun. 2008.

CARVALHAL-DA-SILVA, André Luiz. A influência da estrutura de controle e propriedade no valor, estrutura de capital e política de dividendos das empresas brasileiras. 2003. Tese (Doutorado em Administração) - Instituto COPPEAD de Administração, Universidade Federal do Rio de Janeiro, 2003.

CARVALHAL-DA-SILVA, André Luiz; LEAL, Ricardo Pereira Câmara. Corporate governance index, firm valuation and performance in Brazil. Revista Brasileira de Finanças, v. 3, n. 1, p. 1-18, 2005.

CARVALHAL-DA-SILVA, André Luiz; LEAL, Ricardo Pereira Câmara. Governança Corporativa: evidências empíricas no Brasil. São Paulo: Atlas, 2007.

CHENG, Shijun. Board size and the variability of corporate performance. Journal of Financial Economics, v. 87, n. 1, p. 157-176, jan. 2008.

CHUNG, Kee H.; PRUITT, Stephen W. A simple approximation of Tobin's Q. Financial Management. v. 23, n. 3, p. 70-74, 1994. 
COLEMAN, Anthony Kyereboah; BIEKPE, Nicholas. The relationship between board size, board composition, CEO duality and firm performance: experience from Ghana (2005). Disponível em: <http://www.essa.org.za/download/2005conference/kyereboahcoleman.pdf>Acesso em: Dez/2008.

COLES, Jeffrey L.; DANIEL, Naveen D.; NAVEEN, Lalitha. Boards: does one size fit all? Journal of Financial Economics, v. 87, n. 2, p. 329-356, 2008.

COOPER, Donald R.; SCHINDLER, Pámela S. Métodos de pesquisa em administração. 7. ed. Porto Alegre: Bookman, 2003.

COTTER, James F.; SHIVDASANI, Anil.; ZENNER, Marc. Do independent directors enhance target shareholder wealth during tender offers? Journal of Financial Economics, v. 43, n. 2, p. 195-218, 1997.

DENIS, Diane K. Twenty-five years of corporate governance research ... and counting. Review of Financial Economics, v. 10, n. 3, p. 191-212, 2001.

EISENBERG, Theodore; SUNDGREN, Stefan; WELLS, Martin T. Larger board size and decreasing firm value in small firms. Journal of Financial Economics, v. 48, n. 1, p. 35-54, 1998.

FALEYE, Olubunmi. Classified boards, firm value, and managerial entrenchment. Journal of Financial Economics, v. 83, n. 2, p. 501-529, 2007.

FAMA, Eugene F.; JENSEN, Michael C. Separation of ownership and control. Journal of Law and Economics, paper, v. 26, June 1983a.

FAMA, Eugene F.; JENSEN, Michael C. Agency problems and residual claims. Journal of Law and Economics, v. 26, p. 327-350, 1983 b.

FAMÁ, Rubens; BARROS, Lucas Ayres B. de C. $Q$ de Tobin e seu uso em finanças: aspectos metodológicos e conceituais. Caderno de Pesquisas em Administração, São Paulo, v. 7, n. 4, out./dez. 2000.

FÜERST, Oren, KANG, Sok-Hyon. Corporate governance, expected operating performance, and pricing. Working in Progress, v. 2.2, Yale School of Management, New Haven, CT, 2000 .

GUJARATI, Damodar N. Econometria básica. 4. ed. Rio de Janeiro: Elsevier, 2006.

HART, Oliver. Corporate governance: some theory and implications. The Economic Journal, v. 105(430), p. 678-689, May 1995.

HE, Enya.; SOMMER, David W. Separation of ownership from control: implications for board composition. ARIA Annual Meeting Papers, p. 1-43, Jul. 2006. Disponível em: <http://www.aria.org/meetings/2006papers/He_Sommer_ARIA_2006.pdf $>$.

HELLAND, Eric. SYKUTA, Michael. Who's monitoring the monitor? Do outside directors protect shareholders' interests? Working Paper No. 2003-02, June 2003. 
HERMALIN, Benjamin E.; WEISBACH, Michael S. Boards of directors as an endogenously determined institution: a survey of the economic literature. Economic Policy Review, p. 7-26, Apr. 2003.

HILL, R. Carter; GRIFFITHS, William E.; JUDGE, George G. Econometria. São Paulo: Saraiva, 2006.

INSTITUTO BRASILEIRO DE GOVERNANÇA CORPORATIVA. Código de Melhores Práticas de Governança Corporativa. 3. ed. São Paulo: IBGC, 2004.

IUDÍCIBUS, Sergio de. LOPES, Alexandro Broedel. Teoria avançada da contabilidade. São Paulo: Atlas, 2004.

JENSEN, Michael; MECKLING, Willian. Theory of the firm: managerial behavior, agency cost and ownership structure. Journal of Financial Economics, v. 3(4), p. 305-360, Oct. 1976.

JENSEN, Michael. Agency costs of free cash flow, corporate finance, and takeovers. American Economic Review, v. 76, p. 323-329, 1986.

JENSEN, Michael. The modern industrial revolution, exit, and the failure of internal control systems. Journal of Finance, v. 48, p. 831-880, 1993.

LA PORTA, Rafael et al. Investor protection and corporate finance. Journal of Financial Economics, v. 54, p. 471-517, Oct. 2000.

LEAL; Ricardo P. C.; OLIVEIRA; Claudia L. T. An evaluation of board practices in Brazil. Corporate Governance, v. 2(3), p. 21-25, 2002.

LIPTON, Martin. LORSCH, W. A modest proposal for improved corporate governance. Business Lawyer, v. 48(1), p. 59-77, 1992.

PANASIAN, Cristine; PREVOST, Andrew K.; BHABRA, Harjeet S. Board composition and firm performance: the case of the dey report and publicly listed canadian firms. Working paper, 2004.

ROSS, Stephen A. The economic theory of agency: the principal's problem. The American Economic Review, v. 63(2), p. 134-139, May 1973.

SARTORIS, Alexandre. Estatística e introdução à econometria. São Paulo: Saraiva, 2003.

SHLEIFER, Andrei; VISHNY, Robert. A survey of corporate governnce. Journal of Finance, v. 52(2), p. 737-783, June 1997.

SILVEIRA, Alexandre Di Miceli; BARROS, Lucas Ayres B. de C.; FAMÁ, Rubens. Estrutura de governança e valor das companhias abertas brasileiras. Revista de Administração de Empresas da Fundação Getúlio Vargas, v. 43, n. 3, p. 50-64, 2003.

SILVEIRA, Alexandre Di Miceli. Governança corporativa e estrutura de propriedade: determinantes da relação com o desempenho das empresas no Brasil. 2004. 254 f. Tese (Doutorado em Administração) - Programa de Pós-Graduação em Administração, Faculdade de Economia, Administração e Contabilidade da Universidade de São Paulo, 2004. 
SHIN, Hyun-Han; TULZ, Rene M. Firm value, risk, and growth opportunities. Working Paper, n. 7808. Cambridge: NBER - National Bureau of Economic Research, 2000.

WEISBACH, Michael S. Outside directors and CEO turn over. Journal of Financial Economics, v. 20, p. 431-460, 1988.

YERMACK, David. Higher market valuation of companies with a small board of directors. Journal of Financial Economics, v. 40, n.3, p. 185-213, 1996. 